\title{
Survival of migrating sea trout (Salmo trutta ) smolts during their passage of an artificial lake in a Danish lowland stream
}

\author{
Schwinn, Michael; Aarestrup, Kim; Baktoft, Henrik; Koed, Anders
}

Published in:

River Research and Applications

Link to article, DOI:

$10.1002 /$ rra.3116

Publication date:

2017

Document Version

Peer reviewed version

Link back to DTU Orbit

Citation (APA):

Schwinn, M., Aarestrup, K., Baktoft, H., \& Koed, A. (2017). Survival of migrating sea trout (Salmo trutta ) smolts during their passage of an artificial lake in a Danish lowland stream. River Research and Applications, 33(4), 558-566. https://doi.org/10.1002/rra.3116

\section{General rights}

Copyright and moral rights for the publications made accessible in the public portal are retained by the authors and/or other copyright owners and it is a condition of accessing publications that users recognise and abide by the legal requirements associated with these rights.

- Users may download and print one copy of any publication from the public portal for the purpose of private study or research.

- You may not further distribute the material or use it for any profit-making activity or commercial gain

- You may freely distribute the URL identifying the publication in the public portal 


\title{
SURVIVAL OF MIGRATING SEA TROUT (SALMO TRUTTA) SMOLTS DURING THEIR PASSAGE OF AN ARTIFICIAL LAKE IN A DANISH LOWLAND STREAM
}

\author{
M. SCHWINN, K. AARESTRUP, H. BAKTOFT AND A. KOED* \\ Silkeborg, Denmark
}

\begin{abstract}
Artificial lake development is often used as a management tool to reduce nutrient runoff to coastal waters. Denmark has restored more than 10000 ha of wetlands and lakes in the last 14 years as a consequence of 'Action Plans for the Aquatic Environment', which aim to meet the demands of the European Union's Water Framework Directive. Juvenile, seaward migrating salmonids are highly affected by impounded waterbodies, as they are subjected to extraordinary high mortalities due to predation and altered habitat. From 2005 to 2015 , survival and migration patterns of wild brown trout (Salmo trutta) smolts were investigated by using radio, acoustic and Passive Integrated Transponder telemetry both before and after the development of an artificial lake in a small Danish lowland stream. In 2005 and 2006 , before the lake developed, survival was estimated to be $100 \%$ in the river stretch where the lake later developed. In 2007 and in the period between 2009 and 2015 , mean yearly survival decreased to $26 \%$. Mean time for passing the area increased significantly after the development of the lake from 0.42 to 5.95 days. Generalized additive models were used to model the probability of a successful passage. Water temperature and discharge were key environmental factors affecting survival of the smolts during the passage of the lake. Furthermore, smolt survival was negatively correlated with condition factor. This elevated level of smolt mortality may seriously compromise self-sustaining anadromous salmonid populations when artificial lakes are developed in connection with rivers. Copyright () 2016 John Wiley \& Sons, Ltd.
\end{abstract}

KEY WORDS: passive integrated transponder; acoustic telemetry; radio telemetry; artificial lake; downstream migration; survival; Salmo trutta; salmonids

Received 13 July 2016; Revised 04 November 2016; Accepted 07 November 2016

\section{INTRODUCTION}

The establishment of ponds, lakes or wetlands for the purpose of nutrient removal has become a commonly used management tool internationally (e.g. Grant et al., 2006; Mitsch and Day, 2006; Moreno et al., 2007). The Danish Aquatic Environment Plan II from 1998 supports formation of lakes and wetlands in catchments that receive high nitrogen loads and discharge into vulnerable lakes, fjords and coastal waters (Hoffmann and Baattrup-Pedersen, 2007). This approach is considered cost effective and supportive of the demands imposed by the European Water Framework Directive (European Commission, 2000), which requires all waterbodies to achieve an ecologically good status. Other desirable effects of the development of artificial lakes include recreational opportunities and the potential for new habitats for rare or endangered species. So far, more than 10000 ha of wetland area have been re-established in Denmark (Windolf et al., 2016). Recently, the Ministry of Environment and Food agreed to continue the plans in 2016 and to establish another 1200 ha of wetlands and lakes, co-financed with the European Union (governmental notice, J.nr. NST-4259-00052, 1 December

*Correspondence to: A. Koed, National Institute of Aquatic Resources, Technical University of Denmark, Silkeborg, Denmark.

E-mail: ak@aqua.dtu.dk
2015; http://naturstyrelsen.dk/media/188924/bilag-1-fordelingn-og-p-endelig.pdf). Little attention has been paid to the possible effects of the establishment of artificial lakes or wetlands on fish populations in the connected rivers, streams and brooks, despite it being stated in a governmental notice that the local fauna and flora should benefit from the establishment of these new lakes (governmental order no. 966, 16 December 1998; https://www.retsinformation.dk/forms/ R0710.aspx?id=12115).

Anadromous salmonid populations seem to be severely affected by impounded waterbodies. Smolts face increased mortalities during their seaward migration, mainly due to unknown environments and predation. Mortality is typically high when they are subjected to anthropogenic impoundments like reservoirs, weirs, water abstraction sites or artificial lakes (Aarestrup and Koed, 2003; Gauld et al., 2013; Jepsen et al., 1998; Thorstad et al., 2012). Few peer reviewed studies have focused on the behaviour and mortality of Atlantic salmon (Salmo salar L.) and brown trout (Salmo trutta L.) smolts during their passage of lakes or ponds. Rasmussen et al. (1996) reported a loss of $77.6 \%$ of domesticated brown trout smolts tagged with panjet markers during their passage of the small artificial lake (Lake Bygholm). Furthermore, the authors found a loss of $86.8 \%$ of stocked brown trout smolts at the outlet of the hydropower lake Vestbirk. A loss of approximately $90 \%$, mostly caused 
by increased pike and bird predation, was observed in hatchery reared Atlantic salmon and wild brown trout passing through the Tange Reservoir (Aarestrup et al., 1999; Jepsen et al., 1998). Olsson et al. (2001) observed a mortality of $81.5 \%$ and $77 \%$ with considerable migration delays in a Passive Integrated Transponder (PIT) study monitoring brown trout smolts traversing an artificial pond.

Brown trout is a species of high economic and cultural value related to recreational and commercial fisheries. Further, it serves as an indicator species in the assessment of the ecological status of rivers in Denmark. In this long-term study, we investigated the seaward migration of brown trout smolts during spring before (2005 and 2006) and after (2007 and 2009-2015) the development of Egå Engs $\varnothing$, an artificial lake developed in a small Danish lowland stream. Radio, acoustic, and PIT telemetries were used to investigate the effects on survival and behaviour of migrating smolts. To our knowledge, it is the first study that provides telemetry data on the downstream migration before and after the development of an artificial lake.

\section{METHODS}

\section{Study area}

Egå Engs $\varnothing$ is an artificial lake which was established in October 2006, north of the city Aarhus in Denmark $\left(56^{\circ} 13^{\prime} \mathrm{N}, 10^{\circ} 13^{\prime} \mathrm{E}\right.$, Figure 1$)$. Artificial drainage originally led to land subsidence of the area. By stopping the drainage and by building a low weir in the eastern end of the area, a shallow lake with a mean depth of $0.8 \mathrm{~m}$ and a surface area of $1.12 \mathrm{~km}^{2}$ emerged. The feeding river, Egå, starts approximately $10 \mathrm{~km}$ upstream of Egå Engs $\varnothing$ in Lake Geding and drains into Aarhus Bight $4.1 \mathrm{~km}$ downstream of the lake. The annual mean discharge of Egå into the lake is $0.52 \mathrm{~m}^{3} \mathrm{~s}^{-1}$ and lake retention time was 20 days in 2014 .

Studies before the establishment of the lake (2005 and 2006)

Radio telemetry (2005). In spring 2005, 40 wild brown trout smolts [mean fork length $(\mathrm{FL})=171 \mathrm{~mm}$ ] were caught in a trap in the neighbouring River Lille $\AA$, approximately $30 \mathrm{~km}$ away from the study site. Tagging was conducted on April 18 and 21 by using radio transmitters (Model F1420, Advanced Telemetry Systems, USA; dimensions: $16 \mathrm{~mm}$ length, $8 \mathrm{~mm}$ width, $7 \mathrm{~mm}$ height; weight: $1.3 \mathrm{~g}$ in air, guaranteed lifetime: 20 days). Tagging surgeries were performed following the protocol given by Koed et al. (2006), using non-absorbable suture (Ethilon 4-0 monofilament nylon, Ethicon, USA) and benzocaine (20 $\mathrm{mg} \mathrm{L}^{-1}$ ) as anaesthetic. Once recovered, the fish were released $350 \mathrm{~m}$ upstream of the inlet of the planned lake. Two stationary data loggers (Model D5041, Advanced Telemetry Systems, USA) connected to 9-element Yagi antennas were installed at the planned outlet (Figure 1). Manual tracking was performed every second day between

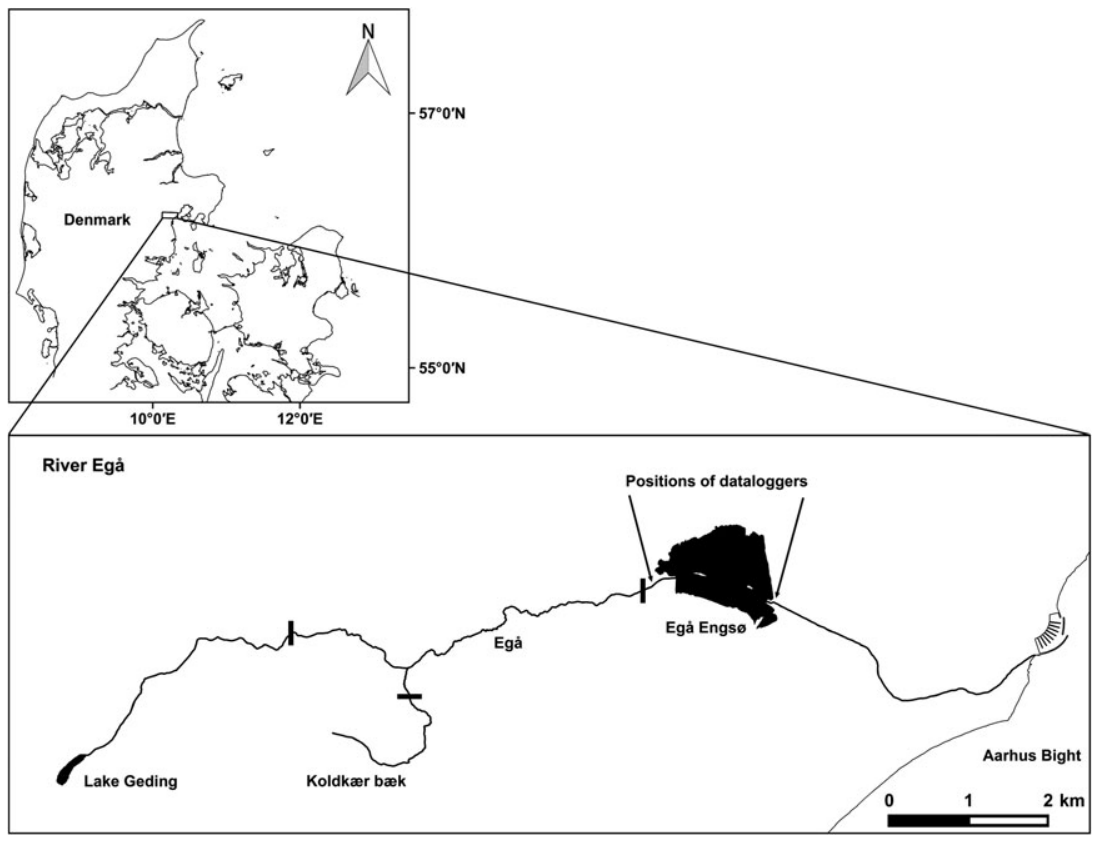

Figure 1. Map showing the River Egå and the Lake Egå Engsø. The positions of the automatic listening station during the radio, acoustic and Passive Integrated Transponder telemetry studies are indicated by arrows. Black bars delimit the stretch of the stream that has been electrofished each spring during the Passive Integrated Transponder study. The distance between the upstream and downstream automatic listening station is $1500 \mathrm{~m}$. 
April 19 and 29 and additionally on May 9 and 17 by using a radio tracking receiver (Model R2100, Advanced Telemetry Systems, USA). On April 27, electrofishing was carried out to investigate the fate of transmitters that remained stable in their position for several days.

Acoustic telemetry (2006). In spring 2006, 30 wild brown trout smolts (mean $\mathrm{FL}=170 \mathrm{~mm}$ ) were caught in a trap in the river Lille $\AA$ (as in 2005). On 4 and 9 May 2006, 5 and 25 smolts were tagged with acoustic radio transmitters respectively (Model V7-2L, Vemco, Canada; $8 \mathrm{~mm}$ diameter, $20 \mathrm{~mm}$ length, weight $1.6 \mathrm{~g}$ in air, guaranteed lifetime: 99 days). Anaesthetization, surgery and release were performed as in 2005 but without piercing through the body wall, as acoustic tags do not have an antenna. To monitor fish movements in the area, four automatic listening stations (ALSs, Model VR2, Vemco, Canada) were set up in the river: two upstream and two downstream of the planned lake (Figure 1). All stations operated continuously during the study period. Manual tracking was performed on May 12, 15,18 , and 30 and on June 6 by using an acoustic tracking receiver (Model VR60, Vemco, Canada).

Studies after the establishment of the lake (2007 and 20092015)

Acoustic telemetry (2007). In spring 2007, fish were caught in a trap in the River Lille $\AA$, as in previous years. On April 13, 30 wild brown trout smolts (mean $\mathrm{FL}=167 \mathrm{~mm}$ ) were tagged with Vemco V7-2L acoustic transmitters, following the procedure from the previous year. Four ALSs (Vemco VR2) were installed at the same positions as in 2006. Manual tracking was performed on April 20 and 25, on May 14, on June 12 and on June 6 by using the VR60 acoustic receiver.

Passive Integrated Transponder telemetry (2009-2015). Every spring, starting in 2009, wild brown trout were caught by electrofishing between mid-February and early March in an approximately $5.5 \mathrm{~km}$ long river stretch upstream of the inlet to a sand trap close to Lake Geding and in the tributary Koldkær bæk from the point of confluence and $500 \mathrm{~m}$ upstream (Figure 1). Electrofishing was carried out by using $500 \mathrm{~V}$ pulsed direct current, produced by a $2000 \mathrm{~W}$ generator (EU 20i, Honda, Japan). Fish with a FL of at least $110 \mathrm{~mm}$ were anaesthetized by using benzocaine $\left(20 \mathrm{mg} \mathrm{L}^{-1}\right)$ until operculum movement slowed significantly (4-5 min). FL $( \pm 1 \mathrm{~mm})$ and weight $( \pm 0.1 \mathrm{~g})$ were measured. PIT tags (type RI-TRP-RRHP, Texas Instruments, USA; half duplex, $134 \mathrm{kHz}$, length $23 \mathrm{~mm}$, diameter $3.85 \mathrm{~mm}$, weight $0.6 \mathrm{~g}$ in air) were implanted into the peritoneal body cavity through a 3 to 4mm-long ventrolateral incision located anterior of the pelvic fins on the left side of the body. Time for measuring, weighing and tagging was less than $20 \mathrm{~s}$ per fish. Fish were recovered (i.e. full equilibrium) and released at the site of capture. A total of 5283 wild brown trout were PIT tagged (Table I).

Two arrays of paired swim-through PIT antennas covering the entire streambed were installed at the inlet and outlet (300 $\mathrm{m}$ upstream and $20 \mathrm{~m}$ downstream of the lake). These antennas generate a radio-frequency electromagnetic field that empowers the circuit of a PIT once in the detection range of approximately $50 \mathrm{~cm}$. The PIT successively sends a unique identification number to an ALS that stores the registration with the date and time. A cycle of $50 / 50 \mathrm{~ms}$ charging/listening time results in a rate of 10 scans per second. Efficiency of the upstream PIT antenna array was calculated based on the total number of individual downstream registrations and missed upstream registrations per year (Table II).

Water level data in the study area were provided from two stations in 15-min intervals: $250 \mathrm{~m}$ upstream of the inlet and $150 \mathrm{~m}$ downstream of the outlet. Discharge at the inlet was calculated by using a $\mathrm{QH}$ curve: $Q=0.36 *(H[\mathrm{~cm}]-21.2)^{2.2}$.

Table I. Overview of methods, number of tagged fish $(N)$, mean fork length (FL), number of fish that entered and left the lake, mean passage time and success rates for each year of the study

\begin{tabular}{|c|c|c|c|c|c|c|c|}
\hline Year & Method & $N$ & $\mathrm{FL} \pm \mathrm{SD}(\mathrm{mm})$ & Entered the lake & Left the lake & Passage time \pm SD [days] & Success rate $[\%]$ \\
\hline 2005 & Radio & 40 & $171 \pm 11$ & \multicolumn{2}{|c|}{ Lake not established } & - & - \\
\hline 2006 & Acoustic & 30 & $170 \pm 10$ & \multicolumn{2}{|c|}{ Lake not established } & $0.42 \pm 0.21$ & - \\
\hline 2007 & Acoustic & 30 & $167 \pm 12$ & 26 & 8 & $1.96 \pm 2.58$ & 31 \\
\hline 2009 & PIT & 959 & $144 \pm 46$ & 814 & 155 & $5.72 \pm 8.33$ & 19 \\
\hline 2010 & PIT & 441 & $143 \pm 41$ & 211 & 50 & $5.36 \pm 5.34$ & 24 \\
\hline 2011 & PIT & 414 & $144 \pm 36$ & 259 & 34 & $6.35 \pm 7.38$ & 13 \\
\hline 2012 & PIT & 548 & $150 \pm 40$ & 288 & 112 & $7.32 \pm 9.00$ & 39 \\
\hline 2013 & PIT & 968 & $140 \pm 23$ & 465 & 123 & $4.92 \pm 4.95$ & 26 \\
\hline 2014 & PIT & 462 & $162 \pm 48$ & 201 & 53 & $5.76 \pm 5.84$ & 26 \\
\hline 2015 & PIT & 1491 & $152 \pm 35$ & 1002 & 326 & $6.07 \pm 7.06$ & 33 \\
\hline Total (PIT) & - & 5283 & $143 \pm 25$ & 3240 & 853 & $5.95 \pm 7.20$ & 26 \\
\hline
\end{tabular}

PIT, Passive Integrated Transponder. 
Table II. Efficiency of the upstream Passive Integrated Transponder (PIT) array. Number of individual downstream registrations per year, missing upstream registrations and efficiency

\begin{tabular}{lccc}
\hline Year & $\begin{array}{c}\text { Downstream } \\
\text { registrations }\end{array}$ & $\begin{array}{c}\text { Missing upstream } \\
\text { registrations }\end{array}$ & $\begin{array}{c}\text { Efficiency } \\
(\%)\end{array}$ \\
\hline 2009 & 155 & 0 & 100 \\
2010 & 51 & 1 & 98 \\
2011 & 34 & 0 & 100 \\
2012 & 117 & 5 & 95.7 \\
2013 & 128 & 5 & 96.1 \\
2014 & 53 & 0 & 100 \\
2015 & 380 & 54 & 85.8 \\
Total & 918 & 65 & 7.1 \\
\hline
\end{tabular}

Two temperature loggers (HOBO TidbiT v2, Onset, USA) positioned at the ALS recorded water temperature in hourly intervals starting on 13 March 2009. Due to technical problems, temperature data are unavailable for 2013 and between 5 March and 4 April 2012.

Using a pole mounted PIT detector, several locations were scanned for PITs: A grey heron (Ardea cinerea) colony, located $10 \mathrm{~km}$ away, was scanned every summer. A great cormorant (Phalacrocorax carbo sinensis) colony, located $35 \mathrm{~km}$ away, that consisted of 738 breeding pairs in 2013 (Bregnballe and Therkildsen 2014) was scanned in 2013. Additionally, two small islands located in the lake and the surrounding area of the lakes' inlet and outlet were scanned in early 2016.

\section{Handling of data and statistical analysis}

Passage time. Passage time was calculated in all studies as the time difference between the first downstream registration and the latest previous upstream registration.

Selection of data. To evaluate the passage success during the spring smolt run, a subset of the initial group of 5283 PIT-tagged fish was created for further analysis. Therefore, only individuals that had a registration at one of the upstream antennas within the period from mid-February to the end of May (day of year 50 and 150) and a possible downstream registration earlier than mid-July (day of year 200) were included in the analysis. Additionally, only fish with a FL less than or equal to $250 \mathrm{~mm}$ were selected, as smolt size usually does not exceed this limit in this latitude and larger individuals most likely were resident brown trout. Fish that registered in another year than the year of tagging were excluded $(N=16)$ due to differences in their lengths and weights compared with the year of tagging. Further, fish that moved through the lake with a speed exceeding two body lengths per second $(N=5)$ were excluded because of possible erroneous registrations or predation. The resulting dataset consisted of 3240 fish.
Probability of passage. Preliminary graphical analysis of the PIT data indicated nonlinear patterns in the relationship between probability of a successful (i.e. downstream registration) passage and environmental parameters. Therefore, data were analysed by applying a binomial generalized additive model (GAM). Covariates were tested for outliers and collinearity following Zuur et al. (2010). Due to missing temperature data from 2013 and in the period from 5 March to 4 April 2012, fish registered in this period were excluded from the analysis $(N=465$ and 34 respectively). Observations connected to extreme discharge levels (3-day moving average $>0.63 \mathrm{~m}^{3} \mathrm{~s}^{-1}$ ) were omitted from the analysis because they do not reflect the regular conditions of the system $(N=135)$. Fish with a Fulton condition factor below 0.815 and above 1.12 were discarded to eliminate potential measurement errors $(N=27)$. Lastly, fish classified as resident brown trout based on their phenotype were omitted $(N=152)$. Covariates not included in the initial model due to collinearity were weight and Julian day of year. Water temperature and discharge at the inlet were used alternatively to the corresponding data at the outlet. Consequently, the following initial model was fitted to the remaining 2427 observations:

$$
\begin{aligned}
& \text { Survival }_{\mathrm{i}} \sim \operatorname{Bin}\left(\pi_{\mathrm{i}}\right) \\
& \mathrm{E}\left(\text { Survival }_{\mathrm{i}}\right)=\pi_{\mathrm{i}} \\
& \operatorname{logit}\left(\pi_{\mathrm{i}}\right)=\alpha+f_{1}\left(\text { Length }_{\mathrm{i}}\right)+f_{2}\left(\text { Fulton }_{\mathrm{i}}\right) \\
& +f_{3}\left(\text { Water Temperature }_{\mathrm{i}}\right)+f_{4}\left(\text { Discharge }_{\mathrm{i}}\right) \\
& +f_{5}\left(\text { Time of } \text { Day }_{\mathrm{i}}\right) \\
& +f_{6}\left(\text { Distance Release Location - Inlet } \mathrm{i}_{\mathrm{i}}\right) \\
& + \text { stage }_{i}+\text { year }_{i}
\end{aligned}
$$

Here, Survival ${ }_{i}$ is the binary response of whether fish $i$ passed the lake or not, $\alpha$ is the common intercept, and $f_{\mathrm{i}}$ indicates smoothing terms. Smoothing parameters are estimated by using the unbiased risk estimator criterion (Wood, 2006). To improve model fit, means and moving averages over different time intervals (1-6 days) were calculated for discharge and water temperature at the inlet and outlet. Based on the Akaike information criteria, the best values were the 4-day mean of water temperature and a moving average of discharge over 3 days, centred at the time of the first registration. Time of day is the number of seconds after midnight the fish entered the lake. Here, a cyclic penalized cubic regression spline was used to estimate a smoother, due to the circular nature of the data. Stage is a two-level factor indicating smoltification status 
(pre-smolt or smolt). Year is a factor differentiating between the single years of tagging. Parsimonious model selection was performed by stepwise single term elimination of nonsignificant terms $(p>0.05)$. Significance of model terms was tested by analysis of residual deviance from singleterm deletions according to Wood (2006). Statistical analysis was performed in $\mathrm{R}$ version 3.3.1 ( $\mathrm{R}$ Development Core Team, 2016) by using mgcv version 1.8-12 (Wood, 2011). Fulton's condition factor is calculated according to Ricker (1975).

\section{RESULTS}

\section{Radio telemetry (2005)}

All 40 tagged fish entered the area of the planned lake. No mortality was observed during the study period, but one smolt disappeared from the study area. Electrofishing showed that two smolts were eaten by pike downstream of the planned lake. One smolt moved upstream and probably desmoltified. Due to the experimental design (no upstream ALS), passage times could not be calculated in that year.

\section{Acoustic telemetry (2006)}

As in 2005, all tagged fish were registered in the study area and no mortality in the region of the future lake was observed. A single smolt was eaten by a pike downstream of the future lake, and another one left the study area upstream. Based on registrations at the ALS, a mean passage time of $0.42 \pm 0.21$ days was calculated as a reference for a later comparison. This value is based on 14 fish because the two upstream ALSs only registered $47 \%$ of the passing smolts, probably due to low efficiency during low water levels, whereas the downstream ALS registered all passing smolts.

\section{Acoustic telemetry (2007)}

Three of the 30 smolts left the study area upstream after an earlier registration in the lake. One transmitter was never detected by the ALS or by manual tracking and assumed to be defective. Eight of the remaining 26 (31\%) smolts successfully passed the newly developed lake. Furthermore, another eight smolts were registered in the proximity of the outlet ALS (receiver range: $144 \mathrm{~m}$ ) but did not leave the lake. Total smolt loss in the lake was $69 \%$ and mean passage time was $1.96 \pm 2.58$ days.

\section{Passive Integrated Transponder telemetry (2009-2015)}

Efficiency of the upstream PIT antenna array during the complete study period was $92.9 \%$, ranging from $85.8 \%$ in 2015 and $100 \%$ in 2009 and 2014 (Table II).
Migration success and final destination. Throughout the complete study period, $853(26 \%)$ of the 3240 tagged individuals that entered Lake Egå Engs $\varnothing$ were registered at the downstream antennas, indicating successful passage (Table I). Migration success per year varied between $13 \%$ and $39 \%$. Out of the 2387 non-exiting fish, 538 returned upstream and 1363 remained in the lake. Four hundred eighty-six fish registered only at one of the upstream antennas, revealing no information about their final destination.

Lake passage time. Mean passage time was $5.95 \pm 7.2$ days (median $=3.31$ days). The yearly mean varied between 4.92 days in 2013 and 7.32 days in 2012 (Table I). Individual movement times varied between $1.55 \mathrm{~h}$ and 65.1 days.

Environmental variables. Mean discharge in the period between February 1 and July 1 varied from 0.260 to $0.491 \mathrm{~m}^{3}$ between the years. Mean water temperatures in the same period varied from 7.6 to $11^{\circ} \mathrm{C}$ at the inlet and from 8.6 to $12.4^{\circ} \mathrm{C}$ at the outlet.

Manual scanning in bird colonies. In total, 111 PIT tags were found at the grey heron colony, while no PIT tags were found in the cormorant colony. During scanning in the proximity of the lake's inlet and outlet and on the islands in January 2016, 76 tags were registered, of which 72 were situated on the eastern island, which is a preferred resting area for great cormorants (Henning Larsen, Danish Ornithological Society, pers. communication).

Probability of passage. Stepwise single-term elimination of non-significant terms $(p>0.05)$ resulted in the following model:

$$
\begin{aligned}
\operatorname{logit}\left(\pi_{\mathrm{i}}\right)=\alpha & +f_{1}\left(\text { Fulton }_{\mathrm{i}}\right)+f_{2}\left(\text { Water Temperature }_{\mathrm{i}}\right) \\
& +f_{3}\left(\text { Discharge }_{\mathrm{i}}\right)
\end{aligned}
$$

Model fit and $95 \%$ confidence intervals are presented in Figure 2, where other covariates in the model are kept at their mean values. The GAM shows a complex pattern for water temperature and discharge. The highest probability of passage is reached at approximately $7^{\circ} \mathrm{C}$. At higher temperatures, up to $11.8^{\circ} \mathrm{C}$, the probability decreases to the minimum value of $20 \%$. Beyond this temperature, it steadily increases again. However, observations below $5^{\circ} \mathrm{C}$ and above $14^{\circ} \mathrm{C}$ were rare, and confidence intervals indicate a higher uncertainty of the model in this temperature range. There is a trend of increasing probability of passage with increasing levels of discharge up to a value of approximately $520 \mathrm{~L} \mathrm{~s}^{-1}$. When discharge surpasses this value, the probability of a successful passage decreases again. But due to the low number of 

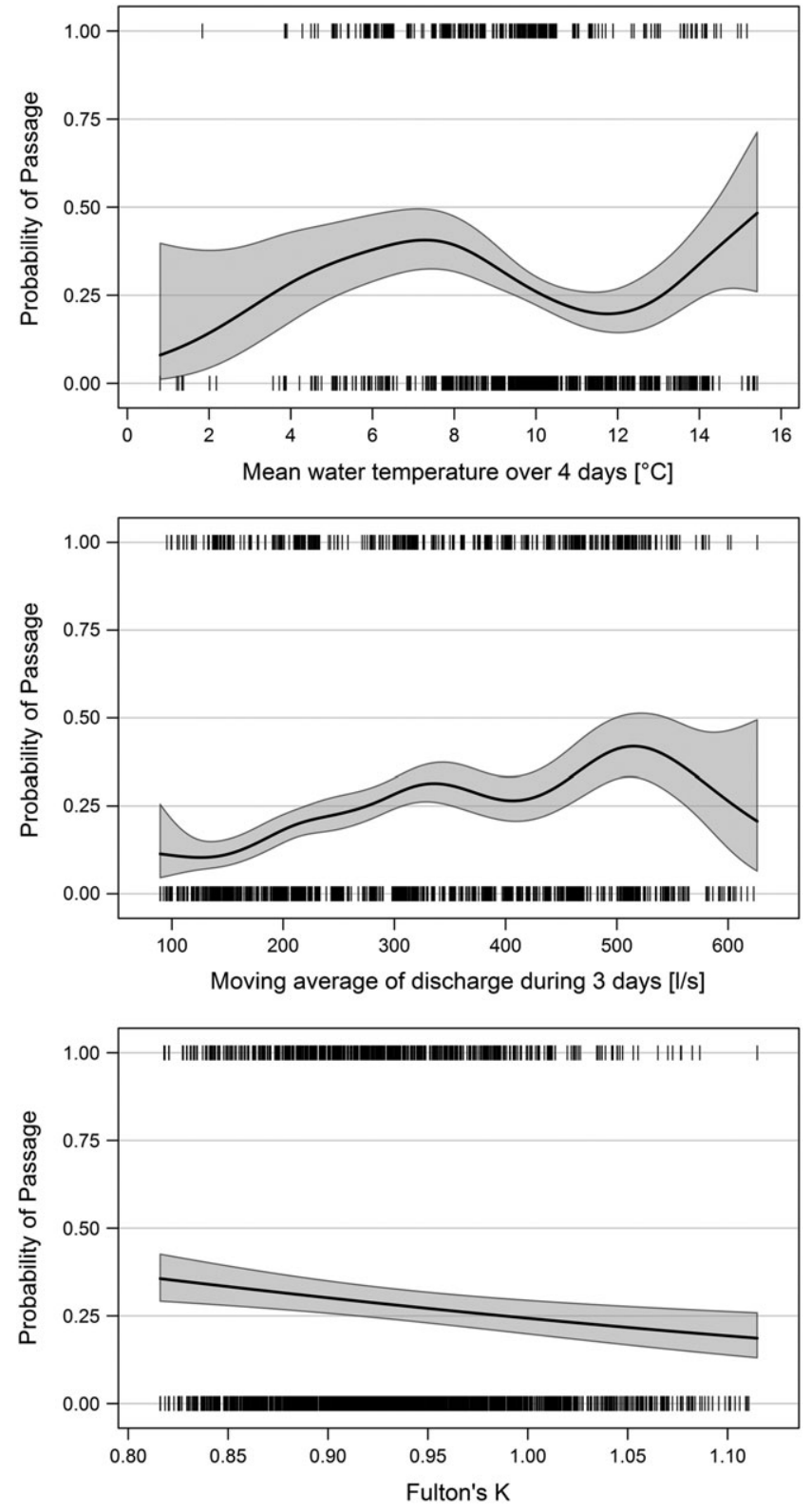

Figure 2. Probability of passage (and 95\% confidence intervals) as a function of discharge, water temperature and Fulton condition factor. Data are predicted values, back-transformed to the original scale, obtained from the generalized additive model.

observations at high discharge levels, the uncertainty of the model is higher there. Fulton condition factor is fitted as a linear effect: With increasing body condition, the probability of a successful passage lowers.

\section{DISCUSSION}

We evaluated the passage of juvenile brown trout smolts in a small Danish lowland river before (2005 and 2006) and after
(2007 and 2009-2015) the development of a shallow lake by using radio, acoustic and PIT telemetries. Experimental fish for the studies in 2005-2007 were collected in a trap that was operating at that time in the neighbouring river Lille $\AA$. Because this trap is located in the same latitude as the study area, no differences in smolt age, timing and behaviour were expected (L'Abee-Lund et al., 1989). Additionally, we did not expect any considerable tagging effects given that previous studies have demonstrated minimal impacts on survival, growth, other physiological factors (e.g. plasma cortisol level, $\mathrm{Na}+$ and $\mathrm{K}+$-ATPase activity) and behaviour of salmonids (Cooke et al., 2011; Jepsen et al., 2008; Larsen et al., 2013; Ostrand et al., 2012; Wagner et al., 2011).

Before the lake developed, the river stretch was a uniform, channelized $1.4 \mathrm{~km}$ long stretch running through an agricultural area, and no mortality of the seaward migrating smolts was observed. High survival was expected because the fish were not exposed to particularly high predation pressure for prolonged periods of time. Additionally, smolts traversed the area primarily during the night, circumventing exposure to diurnal predators.

After the lake was established, the survival decreased to an average of $26 \pm 8 \%$ (SD) per year. Other radio telemetry studies conducted in Denmark (Aarestrup et al., 1999; Jepsen et al., 1998) showed that the main cause for mortality of salmonid smolts passing through lakes is predation by other fish species and birds. The top predator in these habitats is the Northern pike (Esox lucius). It is assumed that a large pike population has established in Lake Egå Engs $\varnothing$ because it qualifies as an ideal habitat. However, no qualitative or quantitative survey about the fish fauna assemblage in the lake is available. Besides Northern pike, other fish species potentially preying on smolts in this system are perch (Perca fluviatilis), European eel (Anguilla anguilla) and larger brown trout. Bird predation may also play a role in the observed elevated mortality. The lake and its surrounding wet meadows attract a rich bird community, among which many species are capable of preying on smolts. These species include the great cormorant (P. carbo), grey heron $(A$. cinerea), great crested grebe (Podiceps cristatus), rednecked grebe (Podiceps grisegena), goosander (Mergus merganser) and red-breasted merganser (Mergus serrator). Quantifying bird predation based on PIT tag recovery gives limited estimates because different bird species use different and potentially unknown locations for excretion of PIT from predated smolts. The increased presence of predators, combined with vastly increased passage times, is likely at cause for the large increase in smolt mortality.

Passage time was calculated for every fish that exited the lake downstream. In 2006, the mean passage time for the stretch before the lake was developed was 0.42 days. This time increased to 5.9 days after the lake was developed. 
However, a direct comparison of these passage times should be made with care, as the 2006 data are based on only eight fish. Nevertheless, our data certainly indicate a major increase in the time needed to traverse the area.

Previous research suggests that downstream movement of smolts is partly a passive displacement coupled with active orientation with currents to increase travelling speed in streams and rivers (Hansen et al., 1984; Moore et al., 1998). A strong correlation between smolt travel time and water flow has been demonstrated (e.g. Aarestrup et al., 2002; Connor et al., 2003; Smith et al., 2002). In the lake Egå Engsø, the main current at the inlet quickly fades and low wind-induced currents provide the main flow within the lake. This lack of a uniform current may play a role in increasing the time that fish need to negotiate the area.

The long water retention time and the shallow depth of the lake lead to higher temperatures in the lake during spring compared with the upstream river temperature. Increased temperatures are known to accelerate desmoltification, a reduction of gill $\mathrm{Na}+$ and $\mathrm{K}+$-ATPase activity leading to reduced osmoregulatory capability and therefore reduced tolerance for seawater and motivation to migrate (McCormick et al., 1999). Other studies hypothesized that anthropogenic obstructions like dams or weirs that delay downstream migration lead to increased desmoltification if the fish do not reach seawater during the physiological smolt window (Aarestrup and Koed, 2003; Garcia De Leaniz, 2008). A temperature-induced desmoltification might also explain why 538 smolts returned upstream.

Different temperature and flow regimes between years as well as varying predator abundances can presumably explain the between-year variation of successful passage ranging from a minimum of $13 \%$ in 2011 to a maximum of $39 \%$ in 2012 . The environmental variables have a significant effect on the probability of a successful passage in the GAM and vary considerably between the years, although we did not quantify predator abundance. The GAM predicts optimal conditions of the environmental variables' water temperature and discharge with respect to successful passage. The smoothing function of water temperature shows the highest probability of successful passage at about $7^{\circ} \mathrm{C}$. A potential underlying cause could be low success and attack rates of pike preying on smolts at low temperatures, as shown by Öhlund et al. (2015). Further, an analysis of bird observation data obtained from the Danish Ornithological Society (dofbasen.dk) showed high abundances of goosander mainly until the beginning of April, when the 4-day mean of water temperature rarely surpassed $7{ }^{\circ} \mathrm{C}$. Goosander is known to prey on seaward migrating smolts (Harris et al., 2008), and high abundances of these birds may additionally explain the relatively low probability of passage below $7^{\circ} \mathrm{C}$. Occurrence of the other birds was more evenly distributed during the smolt run.

The smoothing term of discharge shows increasing probability of passage at high levels of discharge. Ceteris paribus, elevated discharge and thus lower retention time should reduce smolt passage time, and thus the time smolts are subjected to the increased predation pressure in the lake. However, our data do not demonstrate any association between passage time and discharge within the observed range.

The probability of a successful passage declines with increasing Fulton condition factor. Differences in migratory behaviour related to body condition or muscle lipid concentration were previously observed in other studies: Davidsen et al. (2014) found improved migration performance of hatchery smolts that were starved for 176 days prior to release. Increased propensity to migrate was found by Larsson et al. (2012) for hatchery smolts with lower muscle lipid concentrations, and Boel et al. (2014) observed higher condition factors in juvenile brown trout following a resident life history strategy. Our findings support the results of the aforementioned studies. It remains a subject to speculation in which way the body condition affects a successful lake passage. Higher condition factors are typically observed in fish that are not fully smoltified (Folmar and Dickhoff, 1980; Hoar, 1976) and potentially migrate slower compared with fully smoltified fish. However, there was no significant correlation between passage time and Fulton condition factor.

Generally, this elevated level of smolt mortality may not allow for self-sustaining salmonid populations or considerably reduce the anadromous part of the population, potentially shifting fitness in favour of a resident life history strategy. The establishment of artificial lakes, ponds and wetlands jeopardizes ongoing efforts to preserve and to protect salmonids. Passeport et al. (2013) advise against the construction of new reservoirs or artificial lakes for nitrogen management due to well-documented negative hydrological and ecological consequences. Given the ecological and economical values of anadromous brown trout, we strongly recommend the development of techniques to support better smolt passage in existing and planned artificial waterbodies.

\section{ACKNOWLEDGEMENTS}

This study was funded by the Danish Rod and Net Fish License Funds and the Municipality of Aarhus. We wish to thank Jes Dolby for essential technical assistance and Jørgen Skole Mikkelsen for invaluable help in the field.

Handling and tagging of fish was conducted in accordance to the guidelines described in permission 
2005/561-987 and 2012-DY-2934-00007 from the Danish Experimental Animal Committee.

\section{REFERENCES}

Aarestrup K, Koed A. 2003. Survival of migrating sea trout (Salmo trutta) and Atlantic salmon (Salmo salar) smolts negotiating weirs in small Danish rivers. Ecology of Freshwater Fish 12: 169-176.

Aarestrup K, Jepsen N, Rasmussen G, Økland F. 1999. Movements of two strains of radio tagged Altlantic salmon, Salmo salar L., smolts through a reservoir. Fisheries Management and Ecology 6: 97-107.

Aarestrup K, Nielsen C, Koed A. 2002. Net ground speed of downstream migrating radio-tagged Atlantic salmon (Salmo salar L.) and brown trout (Salmo trutta L.) smolts in relation to environmental factors. Hydrobiologia 483: 95-102.

Boel M, Aarestrup K, Baktoft H, Larsen T, Søndergaard Madsen S, Malte H, Skov C, Svendsen JC, Koed A. 2014. The physiological basis of the migration continuum in brown trout (Salmo trutta). Physiological and Biochemical Zoology : PBZ 87: 334-345.

Bregnballe T, Therkildsen OR. 2014. Danmarks ynglebestand af skarver i 2014. Aarhus Universitet, DCE - Nationalt Center for Miljø og Energi. Teknisk rapport fra DCE - National Center for Miljø og Energi nr. 41. http://dc23.au.dk/pub/TR41.pdf

Connor W, Steinhorst R, Burge H. 2003. Migrational behavior and seaward movement of wild subyearling fall Chinook salmon in the Snake River. North American Journal of Fisheries Management 23: 414-430.

Cooke SJ, Woodley CM, Eppard MB, Brown RS, Nielsen JL. 2011. Advancing the surgical implantation of electronic tags in fish: a gap analysis and research agenda based on a review of trends in intracoelomic tagging effects studies. Reviews in Fish Biology and Fisheries 21: 127-151.

Davidsen JG, Daverdin M, Sjursen AD, Rønning L, Arnekleiv JV, Koksvik JI. 2014. Does reduced feeding prior to release improve the marine migration of hatchery brown trout Salmo trutta smolts? Journal of Fish Biology 85: 1992-2002.

European Commission. 2000. Directive 2000/60/EC of the European parliament and of the council of 23 October 2000 establishing a framework for community action in the field of water policy. Official Journal of the European Communities L 327: 1-93.

Folmar LC, Dickhoff WW. 1980. The parr-smolt transformation (smoltification) and seawater adaption in salmonids. A review of selected literature. Aquaculture 21: 1-37.

Garcia De Leaniz C. 2008. Weir removal in salmonid streams: implications, challenges and practicalities. Hydrobiologia 609: 83-96.

Gauld NR, Campbell RNB, Lucas MC. 2013. Reduced flow impacts salmonid smolt emigration in a river with low-head weirs. Science of the Total Environment 458-460: 435-443.

Grant R, Nielsen K, Waagepetersen J. 2006. Reducing nitrogen loading of inland and marine waters - evaluation of Danish policy measures to reduce nitrogen loss from farmland. AMBIO: A Journal of the Human Environment 35: 117-123.

Hansen LP, Jonsson B, Døving KB. 1984. Migration of wild and hatchery reared smolts of Atlantic salmon, Salmo salar L., through lakes. Journal of Fish Biology 25: 617-623.

Harris CM, Calladine JR, Wernham CV, Park KJ. 2008. Impacts of piscivorous birds on salmonid populations and game fisheries in Scotland: a review. Wildlife Biology 14: 395-411.

Hoar WS. 1976. Smolt transformation: evolution, behavior, and physiology. Journal of the Fisheries Research Board of Canada 33: 1233-1252.
Hoffmann CC, Baattrup-Pedersen A. 2007. Re-establishing freshwater wetlands in Denmark. Ecological Engineering 30: 157-166.

Jepsen N, Aarestrup K, Økland F, Rasmussen G. 1998. Survival of radiotagged Atlantic salmon (Salmo salar L.) and trout (Salmo trutta L.) smolts passing a reservoir during seaward migration. Hydrobiologia 371/372: 347-353.

Jepsen N, Christoffersen M, Munksgaard T. 2008. The level of predation used as an indicator of tagging/handling effects. Fisheries Management and Ecology 15: 365-368.

Koed A, Baktoft H, Bak BD. 2006. Causes of mortality of Atlantic salmon (Salmo salar) and brown trout (Salmo trutta) smolts in a restored river and its estuary. River Research and Applications 22: 69-78.

L'Abee-Lund JH, Jonsson B, Jensen AJ, Saettem LM, Heggberget TG, Johnsen BO, Naesje TF. 1989. Latitudinal variation in life-history characteristics of sea-run migrant brown trout Salmo trutta. Journal of Animal Ecology 58: 525-542.

Larsen MH, Thorn AN, Skov C, Aarestrup K. 2013. Effects of passive integrated transponder tags on survival and growth of juvenile Atlantic salmon Salmo salar. Animal Biotelemetry 1: 19.

Larsson S, Serrano I, Eriksson L. 2012. Effects of muscle lipid concentration on wild and hatchery brown trout (Salmo trutta) smolt migration. Canadian Journal of Fisheries and Aquatic Sciences 69: 1-12.

McCormick SD, Cunjak RA, Dempson B, O’Dea MF, Carey JB. 1999. Temperature-related loss of smolt characteristics in Atlantic salmon (Salmo salar) in the wild. Canadian Journal of Fisheries and Aquatic Sciences 56: 1649-1657.

Mitsch WJ, Day JW. 2006. Restoration of wetlands in the MississippiOhio-Missouri (MOM) River Basin: experience and needed research. Ecological Engineering 26: 55-69.

Moore A, Ives S, Mead TA, Talks L. 1998. The migratory behaviour of wild Atlantic salmon (Salmo salar L.) smolts in the River Test and Southampton Water, southern England. Hydrobiologia 371/372: 295-304.

Moreno D, Pedrocchi C, Comín FA, García M, Cabezas A. 2007. Creating wetlands for the improvement of water quality and landscape restoration in semi-arid zones degraded by intensive agricultural use. Ecological Engineering 30: 103-111.

Öhlund G, Hedström P, Norman S, Hein CL, Englund G. 2015. Temperature dependence of predation on the relative performance of predators and prey. Proceedings of the the Royal Society B: Biological Sciences. 282: 20142254.

Olsson IC, Greenberg LA, Eklöv AG. 2001. Effect of an artificial pond on migrating brown trout smolts. North American Journal of Fisheries Management 21: 498-506.

Ostrand K, Zydlewski G, Gale W, Zydlewski J. 2012. Long term retention, survival, growth, and physiological indicators of juvenile salmonids marked with passive integrated transponder tags. Advances in Fish Tagging and Marking Technology. American Fisheries Society, Symposium 76, Bethesda, Maryland 135-145.

Passeport E, Vidon P, Forshay KJ, Lazar J, Mayer P, Stander EK. 2013. Ecological engineering practices for the reduction of excess nitrogen in human-influenced landscapes : a guide for watershed managers. Environmental Management 51: 392-413.

Development Core Team R. 2016. R: A Language and Environment for Statistical Computing. R Foundation for Statistical Computing: Vienna, Austria http://www.R-project.org/.

Rasmussen G, Aarestrup K, Jepsen N. 1996. Mortality of sea trout (Salmo trutta L.) and Atlantic salmon (Salmo salar L.) smolts during seaward migration through rivers and lakes in Denmark. ICES C.M. 1996/T:9. Anadromous and Catadromous Fish Committee, International Council for the Exploration of the Sea: Copenhagen, Denmark.

Ricker WE. 1975. Computation and interpretation of biological statistics of fish populations. In Bulletin 191 of the Fisheries Research Board of 
Canada. Department of the Environment Fisheries and Marine Service: Ottawa; $1-382$.

Smith SG, Muir WD, Williams JG, Skalski JR. 2002. Factors associated with travel time and survival of migrant yearling Chinook salmon and steelhead in the lower Snake River. North American Journal of Fisheries Management 22: 385-405.

Thorstad EB, Whoriskey F, Uglem I, Moore A, Rikardsen AH, Finstad B. 2012. A critical life stage of the Atlantic salmon Salmo salar: behaviour and survival during the smolt and initial post-smolt migration. Journal of Fish Biology 81: 500-542.

Wagner GN, Cooke SJ, Brown RS, Deters KA. 2011. Surgical implantation techniques for electronic tags in fish. Reviews in Fish Biology and Fisheries 21: 71-81.
Windolf J, Tornbjerg H, Hoffmann CC, Poulsen JR, Blicher-Mathiesen G, Kronvang B. 2016. Successful reduction of diffuse nitrogen emissions at catchment scale: example from the Pilot River Odense, Denmark. Water Science and Technology 73: 1-7.

Wood SN. 2006. Generalized, Additive Models : An Introduction with R. Chapman and Hall/CRC: Chapman \& Hall/CRC, Boca Raton, Florida.

Wood SN. 2011. Fast stable restricted maximum likelihood and marginal likelihood estimation of semiparametric generalized linear models. Journal of the Royal Statistical Society, Series B (Statistical Methodology) 73: 3-36.

Zuur AF, Ieno EN, Elphick CS. 2010. A protocol for data exploration to avoid common statistical problems. Methods in Ecology and Evolution 1: 3-14. 